\title{
Sağlık Yönetiminde Çağdaş Yaklaşımlar ${ }^{1}$
}

\author{
Sibel GÖK ${ }^{1 *}$ \\ ${ }^{1}$ Asst. Prof. Dr., Şırnak University, Silopi Vocational School, Department of Marketing and Foreign Trade, \\ Şırnak, Turkey
}

Geliş Tarihi/Received: 14.01.2021

Doi: 10.31200/makuubd.860953

Kabul Tarihi/Accepted: 17.02.2021

Derleme Makalesi/Review Article

\section{ÖZET}

Toplumun sağlık düzeyinin korunmasında ve geliştirilmesinde sağlık yönetimi çok önem arz etmektedir. Sağlık yönetiminin başarılı bir şekilde gerçekleştirilebilmesi için yönetim sürecinde bilimsel yöntemlerin kullanılması gerekir. $\mathrm{Bu}$ nedenle, yönetimde etkinliği ve verimliliği artırmak üzere ortaya çıkan ve çağdaş yönetim yaklaşımları olarak adlandırılan yönetim yaklaşımları sağlık yönetiminde de uygulanmalıdır. Çünkü modern ve bilimsel bir yönetim tarzı benimsemek çağdaş yönetim yaklaşımlarını sağlık yönetiminde uygulamak ile mümkün olur. Bu çalışmanın amacı, sağlık yönetiminde uygulanması gereken çağdaş yönetim yaklaşımları ile ilgili bilgi vermek ve bu yaklaşımların sağlık yönetimi açısından yerini ve önemini tartışmaktır. Bu kapsamda sağlık yönetiminde çağdaş yönetim yaklaşımlarını temsil etmesi bakımından toplam kalite yönetimi, performans yönetimi ve toplantı yönetimi değerlendirilecektir.

Anahtar kelimeler: Sağlık Yönetimi, Çağdaş Yönetim Yaklaşımları, Toplam Kalite Yönetimi, Performans Yönetimi, Toplantı Yönetimi.

\footnotetext{
${ }^{1}$ Bu makale, Kahramanmaraş Sütçü İmam Üniversitesi Sosyal Bilimler Enstitüsü Kamu Yönetimi Anabilim Dalı'nda Prof. Dr. Ahmet Hamdi AYDIN danışmanlığında Sibel GÖK tarafindan 2019 y1lında tamamlanan Tarihsel Süreç İçerisinde Türkiye Kamu Hastaneleri Kurumu Ve İl Kamu Hastaneleri Birlikleri: Yönetim Ve Örgütlenme Bağlamında Bir Değerlendirme başlıklı doktora tezinden üretilmiş̧ir. Ayrıca bu doktora tezi Kahramanmaraş Sütçü İmam Üniversitesi Bilimsel Araştırma Projeleri Koordinasyon Birimi tarafindan desteklenmiştir.
}

* Sorumlu yazar/Corresponding author

E-mail/e-ileti: goksibel@outlook.com 
Gök, $S$.

\section{Contemporary Approaches in Health Management}

\section{ABSTRACT}

Health management is very important in protecting and improving the health level of the society. Scientific methods should be used in the management process in order to be successful in health management. For this reason, management approaches that emerged to increase efficiency and productivity in management and called modern management approaches should also be applied in health management. Because adopting a modern and scientific management style is possible with applying contemporary management approaches in health management. The aim of this study is to give information about contemporary management approaches that should be applied in health management and to discuss the place and importance of these approaches in terms of health management. In this context, total quality management, performance management and meeting management will be evaluated in terms of representing contemporary management approaches in health management.

Keywords: Healthcare Management, Contemporary Management Approaches, Total Quality Management, Performance Management, Meeting Management.

\section{GİRIŞ}

Yönetim önemlidir ancak söz konusu sağlık yönetimi olduğunda ayrı bir önem arz eder. Çünkü sağlık yönetimi öncelikli olarak insan ve dolayısıyla toplum sağlı̆̆ı ile ilgili olduğundan doğrudan yaşamsal faaliyetleri etkiler. Bir ülkenin toplumsal açıdan refahı sağlıklı bireylerin varlığına bağlıdır. Bu nedenle sağlık yönetiminde sağlanan başarı en başta kamu olmak üzere genel anlamda yönetsel başarıyı da beraberinde getirir.

Birey ve dolayısıyla toplum sağlığının korunması ve geliştirilmesi çabaları sağlık yönetimi süreci içinde değerlendirilir. Sürecin başarısı ise yönetimde uygulanan yöntemlerle ilgilidir. Yönetim bir bilimdir ve bu özelliğinden dolayı sürekli olarak güncellenip yenilenmektedir. $\mathrm{Bu}$ nedenle yönetimde uygulanmak üzere ortaya çıkan çağdaş yönetim yaklaşımları olarak adlandırılan yaklaşımlar bulunmaktadır. Söz konusu yaklaşımların sağlık yönetimi sürecinin tamamında uygulanması gerekir. Çünkü bu yaklaşımların amacı yönetimde etkililiği ve verimliği artırmaktır. Sağlık yönetimi de birey ve toplum sağlığı ile ilgili olduğundan, çağdaş yönetim yaklaşımlarının sağlık yönetiminde uygulanması halinde sağlık yönetiminde etkinlik ve verimlilik de artış olacaktır. Sağlık yönetiminde etkinlik ve verimliliğin artması ile de birey ve toplum sağlığında iyileşme ve ilerleme sağlanacaktır. 
Bu çalışmanın temel amacı sağlık yönetiminde uygulanması gereken çağdaş yönetim yaklaşımlarını değerlendirmektir. Bu kapsamda, ilk olarak sağlık yönetimi ve sağlık yönetimi fonksiyonları hakkında bilgi verilecek daha sonra sağlık yönetiminde uygulanması gereken çağdaş yönetim yaklaşımlarını temsil etmesi bakımından toplam kalite yönetimi, performans yönetimi ve toplantı yönetimi tartışılacaktır.

\section{SAĞLIK YÖNETIMI}

\subsection{Anlamı, Kapsamı ve Niteliği}

Sağlık yönetimi kavramını tanımlamadan önce yönetim kavramını tanımlamak yerinde olacaktır. Yönetim kavramının pek çok tanımı vardır. Ancak literatürde itibar edilen ve sıklıkla karşılaşılan tanımlardan bazılarına göre yönetim; maddi ve beşeri kaynakların, belirli bir amacın gerçekleştirilmesi için düzenlenmesi ve kullanılması faaliyeti veya süreci (Eryılmaz, 2009: 3); yönetmek ve yönlendirmek (Fişek, 1975: 235); örgütün amaçlarını gerçekleştirmek için planlama, örgütleme, yöneltme, ve denetim süreçleri yoluyla bütün kaynakların eşgüdümlenmesi (Ergun ve Polatoğlu, 1988: 4); eş amaçlı kişilerin yer aldıkları bir örgütün amaçlarını gerçekleştirmek için yaptığg eylemlerden meydana gelen bir süreç (Fişek, 1983: 105); iş birliğine dayanan küme davranışı (Sımon vd., 1985: 1); kamu ya da özel sektör kuruluşlarının belirlenen amaçların gerçekleştirilmesi doğrultusunda planlanması, örgütlenmesi, yönlendirilmesi, koordine edilmesi ve denetlenmesi (Aydın, 2012: 39); şeklinde açıklanabilir.

Dolayısıyla bu açıklamalar ışığında yönetim kavramı tanımlanacak olursa; belirlenen bir amacı gerçekleştirmek üzere maddi ve maddi olmayan kaynakların yönetimin beş temel fonksiyonu yerine getirilmek suretiyle (planlama, örgütlenme, yönetme, koordinasyon ve denetleme) sevk ve idare edilmesi, yönlendirilmesi faaliyeti ya da sürecidir. $\mathrm{Bu}$ tanımlardan yola çıkılarak yönetim olgusunun kamu- özel sektör fark etmeksizin ortak bir kavram olduğu anlaşılmaktadır. Sağlık yönetimi açısından bakıldığında ise sağlık kurumlarının hem kamu ham de özel olmak üzere her iki kolda da faaliyet gösterdiği görülür. Örneğin bir yanda devlet hastaneleri diğer tarafta özel hastaneler gibi. Bu nedenle aşağıda sağlık yönetimi ile ilgili çağdaş yönetim yaklaşımları açıklanırken söz konusu yaklaşımlar hem kamu hem de özel sektörde sağlık yönetimi bakımından değerlendirilecektir.

Yaşadığımız yüzyılda yönetim hem bir bilim hem de bir sanattır. Çünkü yöneticinin, yöneticisi olduğu teşkilatta ya da kuruluşta, var olan kaynakları en iyi şekilde kullanma ve 
insanları etkili ve verimli bir biçimde çalıştırma görev ve sorumluğu bulunmaktadır. Dolayısıyla, yönetim daha çok, insan yönetme sanatı ve bilimidir (Aytürk, 1990: 1). Ayrıca yönetim yöntem bakından evrensel olup, uygulama bakımdan ise kültüre bağımlı bir bilimdir.

Sağlık yönetimi kavramını ise; bir topluma sağlık hizmeti vermek amacı ile bir örgütte çalışan bireylerin yaptıkları işlerden meydana gelen bir süreci inceleyen bir bilim olarak ifade etmek mümkündür (Fişek, 1983: 9). Sağlık yönetimi ya da sağlık kurumları yöneticiliği günümüzde ayrı bir bilim dalı olarak yönetim biliminin alt uygulama alanı durumuna gelmiştir. Sağlık kurumları yönetimi, birey ve toplumların sağlık seviyelerini korumak ve aynı zamanda geliştirmek maksadıyla sağlık hizmetleri üretimi için gerekli olan maddi ve beşeri kaynakların planlanması, örgütlenmesi, harekete geçirilmesi ve denetlenmesi süreci şeklinde tanımlanabilir (Tengilimoğluvd; 2014: 551). Sağlık kurumları işletmeciliği; sağlık hizmetleri üretimi vasıtasıyla toplumun sağlık seviyesini korumak ve geliştirmek için maddi ve insan kaynaklarının planlanması, örgütlenmesi, harekete geçirilmesi ve denetlenmesi sürecidir. Sağlık kurumları işletmeciliği, sağlık kurumunun bilimsel işletmecilik temellerine göre yönetilmesidir (Kavuncubaşı, 2002: 47).

Yönetim sürecinin, neyin ne zaman, kim tarafindan ve nasıl sorularının cevaplarının verildiği planlama ile başladığını, örgütleme, yöneltme ve son olarak da belirlenen amaçlara ulaşılıp ulaşılmadığını ve ulaşılma derecesinin kontrolünün denetleme ile sağlandığı söylemek mümkündür. Belirlenen amaçlara ulaşılmış olunsa dahi hep en iyiye ulaşmak için bu süreç bitmeyecek ve planlama ile tekrar başlayacaktır (Çelik, 2012: 79). Çeşitli kaynaklarda yönetim süreci/yönetimin işlevleri farklı şekillerde sınıflandırılmıştır. Örneğin Sözen yönetim sürecini (2003: 13) veri toplama (durum saptama), öncelikleri belirleme, karar verme, planlama, örgütleme, yürütme, iletişim, yöneltme, koordinasyon ve denetim-değerlendirme şeklinde belirlemiştir. Tengilimoğlu vd. (2014: 40) yönetimin işlevlerini planlama, örgütleme, kaynakları bir araya getirme, yön verme ve kontrol olarak incelemiştir. Kavuncubaşı ve Yıldırım (2012: 105) ve Çelik (2012: 79) yönetim sürecini planlama, örgütleme, yöneltme, denetim olmak üzere 4 kategoride açıklamıştır. Fişek (1983: 107) sağlık yönetiminin 7 unsurunu; planlama, örgütlenme, yönlendirme, insan gücü, finansman, eşgüdüm ve denetim olarak açıklamıştır.

Yukarıda verilen kaynaklarda yönetim(in) işlevleri/fonksiyonları/süreci farklı şekillerde sınıflandırılmış olmasına karşın temelde hepside ortak olarak planlama, örgütleme, yöneltme (yönetme), koordinasyon (eşgüdümleme) ve denetleme'den oluşan sınıflandırmayı yapmış 
olmaktadır denebilir. Örneğin bazı kaynaklar veri toplama, öncelikleri belirleme ve karar verme başlıklarını planlama işlevi içinde değerlendirmektedir. Sağlık yönetimi süreci diğer bir ifadeyle sağlık yönetimi fonksiyonları burada; planlama, Örgütlenme, yönetme (yöneltme), koordinasyon (eşgüdüm) ve denetleme (kontrol) olmak üzere 5 başlık altında incelenecektir.

\subsubsection{Planlama}

İleriye bakma ve ileriyi düşünme olarak da açıklanabilen planlama, eski bir kavram ve yönetsel bir fonksiyon olmakla beraber, yönetim konusunda gittikçe önemli hale gelen rolünden dolayı, günümüzde büyük önem kazanmıştır (Aydın, 2011: 34). Planlama, kaynak kullanımın, daha evvel belirlenen amaç ve öncelikler yönünde kontrol altına alınması ve amaçlara uygun şekilde ve tek elden kullanılması (Fişek, 1983: 106); İleriyi önceden görmek, bir başka ifadeyle belirli bir hareketi, yürütme sırasında değil, önceden kararlaştırmak(Tortop vd., 2010: 38); Bir amacın gerçekleştirilmesi için nelerin, nasıl, neden, ne zaman, ne ile ve kim tarafindan yapılacağının önceden kararlaştırılarak bir hareket tarzının belirlenmesidir (Aydın, 2006: 3).

Plan, hem etkinliği çoğaltır, hem de uygulama sonuçlarının takibine yarayan bir ölçüt olarak geleceğe yönelik çalışmalarda gerekli düzenlemelerin, düzeltmelerin yapılmasına imkân tanır (Fişek, 1983: 106). Örgütlerin yönetilmesi için, önce amaçların belirlenmesi, izlenen politikaların geliştirilmesi ve bir yürütme planının hazırlanması zorunludur. Kuruluşların çalışmalarının başarısı, planların iyi hazırlanmasına ve başarılı olmasına bağlıdır (Tortop vd., 2010: 38).

Bir plan yapabilmek için yöneticinin mevcut sorunlardan, ihtiyaçlardan ve imkânlardan haberdar olması gerekir. Bu yüzden plan çalışmaları her zaman durumun saptanması ile başlar (Fişek, 1983: 108). Yapılanlar ve yapılmayanlar ortaya konularak mevcut durum belirlenir. Mevcut durum hakkında bilgi sahibi olunmadan karar verilemez. Veri toplama işlemi yapılarak durum belirlenir. Veriler; yazılı kayıtlardan, belgelerden çıkartılmak suretiyle ya da araştırma, inceleme yoluyla edinilebilir. Bu verileri edinmek amaciyla fotoğraf da çekilebilir, sesli görüntülü kayıt da alınabilir. Örneğin hastane servisinde ya da sağlık ocağına (sağlık ocakları yerini aile hekimliğine bırakmıştır) bağlı bir köyde çalışan bir ebe-hemşire ya da sağlık personeli; Türkiye genelindeki ve bölgesindeki sağlıkla ilgili olan verileri, göstergeleri elde eder, servisiyle/köyüyle ilgili verileri kayıtları çalışmaları tetkik eder, servisiyle/köyüyle ilgili kısa bir inceleme ve araştırma da bulunur, servisinde/köyündeki sorunları saptar ve bu sorunlara çözüm yolları üretmeye çalışır vs. (Sözen, 2003: 13). 
Planlama, örgüt çalışmalarının tanımlanmış ve kararlaştırılmış amaçlara yönelmesini sağlar. Plan olmadan faaliyetler arasında bir koordinasyon sağlansa da, planı yapılmayan faaliyetler, rastgele, işlevsel olmayan ve örgüt amaçlarından sapan bir tarafa doğru gidecektir. Fakat gelecek hiçbir zaman tüm yönleriyle kestirilemez ve planlanamaz. Bu nedenle planların ihtimallere karşı hazırlıklı olması ve muhtemel olan her durumda katı olmayan yani esnek planların hazırlanması gerekir (Çelik, 2012: 79).

Hizmet üretilirken, görev yaparken ilk olarak nelerin yapılacağının, nelerin daha önemli olduğunun kararının verilmesi gerekir. Hem insan hakları evrensel beyannamesi hem de dünya sağlık örgütü (WHO) anayasası her insanın sağlık hizmetlerinden en üst seviye de faydalanmasının, her insanın sağlıklı, uzun bir yaşam sürmesinin birinci temel insan hakkı olduğunu kabul etmiştir. Türkiye Cumhuriyeti anayasası da sağlık hizmetlerini devletin görevi olarak görmektedir. Her kademede bulunan yönetici sağlık ve sağlık ile ilgili hizmetlere öncelik sağlamalıdır. Sağlık yöneticileri ise toplumda sık rastlanan, en çok can ve iş gücü kaybına neden olan halk sağlığı sorunlarına öncelik tanımalıdır (Sözen, 2003: 14). Oluşturulan kararların toplum/birey faydası gözetilerek, adil, gerçekçi, zamana uygun, uygulanabilir ve işinin uzmanı kişi ya da kişilerce alınması gerekmektedir. Aksi takdirde verilen kararlardan sadece bir birey değil bir toplumun etkilenmesi söz konusu olabilir.

Öncelik belirlendikten sonra mevcut durumun değerlendirmesi yapılır. Elde bulunan araç-gereç-malzeme, başka yer ve kurumlardan sağlama olanağı, personel durumu değerlendirilir. Mevcut durumun değerlendirmesi ne kadar sağlıklı yapılırsa planlama da o kadar sağ lıklı ve gerçekçi olur. Bir sonraki aşama zamanlamadır. Zamanlama, uygulanacak plan aşamalarının önceden planlanması anlamına gelmektedir. Tecrübe, zamanlamanın daha isabetli olmasını mümkün kılan önemli bir unsurdur. Zaman planlanması yapıldıktan sonra ise karar verilir (Sözen, 2003: 14-15).

Çoğunlukla planlamanın ülke ya da bölge düzeyinde yapılacağının akla geldiğini, esasen en küçük kademede bulunan yöneticiden en üst kademede görev yapan yöneticiye kadar herkesin plan yapmayı, uygulamayı ve değerlendirmeyi bilmesi ve sahip olduğu bu bilgiyi de kullanması gerektiğini savunan Fişek, Bu sebeple, planlamanın yönetimin kutsal kitabıdır sözünün bir belit olduğunu ifade eder (1983: 108). Sağlık hizmetlerinde planlamanın kapsamlı ya da daha küçük ölçekli planlamalar olmak üzere ortaya çıktığı durumlar söz konusudur. 
Geniş anlamda planlamaya örnek olarak; 1960 tarihinde kurulan Devlet Planlama Teşkilatı ve Sağlık Bakanlığı Araştırma Planlama Kurulu verilebilir. Dar anlamda planlamaya ise; bir köy ebesinin yapmış olduğu aylık çalışmalarını ya da bir hemşirenin hastasına uygulamış olduğu bakım planını yahut bir öğretmenin günlük planı örnek gösterilebilir (Sözen, 2003: 20-21). (2011 yılında Devlet Planlama Teşkilatı yerini Kalkınma Bakanlığı'na bırakmıştır).

Türkiye'de Sağlık hizmetlerinin planlamasını yapma görevinden birinci dereceden sorumlu kurum Sağlık Bakanlığı'dır. 181 sayılı Sağlık Bakanlığının Teşkilat ve Görevleri Hakkında Kanun Hükmünde Kararname'de "Herkesin hayatını bedenen, ruhen ve sosyal bakımdan tam iyilik hali içinde sürdürmesini sağlamak için fert ve toplum sağlığını korumak ve bu amaçla ülkeyi kapsayan plan ve programlar yapmak, uygulamak ve uygulatmak, her türlü tedbiri almak, gerekli teşkilâtı kurmak ve kurdurmak" bakanlığın görevleri arasında ilk sırada yer almıştır.

\subsection{2. Örgütlenme}

Örgüt, etkinlikleri ve etkileşimleri amaca yönelik olarak yapılandırılmış bir küme insan; örgütleme ise bir örgütteki kaynakların tümünün düzenli şekilde kullanılmasını sağlayacak biçimde örgütsel yapının oluşturulması süreci olarak ifade edilir (Ergun, 2015: 77).Örgütler önemlidir çünkü bireyler zamanlarının çok büyük bir kısmını örgütlerin içinde geçirir. Örneğin, yetişkin nüfusun büyük bir çoğunluğu zamanının üçte birinden fazlasını istihdam edildiği örgütlerde geçirir. Benzer şekilde çocuklar da hemen hemen aynı ölçüde hayatlarını okul örgütünün içinde geçirir (March ve Simon, 1975: 2; Aydın, 2011: 50). Dolayısıyla sağlık örgütünü oluşturan personel ve hatta sağlık hizmetini almak için gelen bireylerde zamanlarının bir kısmını sağlık hizmeti veren kurumlarda dolayısıyla sağlık örgütlerinde geçirir.

Örgütleme fonksiyonu bazen örgütün planlarını hayata geçirmek için eldeki kaynakların düzenlenmesi çalışmalarının hepsini içine alan bir örgüt yapısı kurma süreci olarak da tarif edilmektedir. Çünkü örgütleme fonksiyonu ile örgüt içinde yapılması gereken işler parçalara ayrılmakta, gruplanmakta ve koordine edilmektedir. Böyle bir yapı kurulmaksızın örgüt içinde yapılması gereken birçok çalışmanın kendisinden beklenilen sonuçları ortaya koyması mümkün olmayacaktır. $\mathrm{Bu}$ yapı içinde çalışan ve tüm kademedeki yöneticilerin yetki ve sorumluluk ilişkilerinin açıklanması, işbölümü ve iş tasarımından hareketle örgüt içindeki birimlerin tayin edilmesi, birimler arasındaki eşgüdüm şeklinin nasıl olacağının açıklanması ve gereksinim 
duyulan bilgiyi zamanlı ve doğru bir biçimde üretecek olan bilgi sisteminin tasarlanması çalışmaları yapılmaktadır (Çelik, 2012: 80).

Sağlık hizmetlerin örgütlemede dikkate alınacak ilkeler bir ülkenin sosyal güvenlik politikasına bağlı olarak oluşturulur. Eğer sosyal politika ekonomik açıdan gücü yetenin sağlık hizmetini satın almasını öngörüyor ve herkese tedavi hekimliği sunmanın bir kamu hizmeti olmadığ1 merkezinde ise böyle bir ülkede sağlık hizmetlerini örgütleme diye bir sorunun varlığından bahsedilemez. Bu ülkelerde doktor, sağlık personeli, tesis ve hizmet dağılımı, serbest piyasa ekonomisi kurallarına göre, kendiliğinden meydana gelir. Hekimlik hizmetleri arasında koruyucu hekimlik hizmeti mecburi ve para ile satın alınmayan bir hizmet olduğundan dolayı bu hizmetler her ülkede hükümetler tarafindan örgütlenen ve finanse edilen hizmetler arasındadır (Fişek, 1983: 113).

Belirlenen birtakım amaçlarını hayata geçirebilmek için bir araya gelmiş insanların meydana getirdiği bir yapı olan örgüt, çevresiyle yoğun bir etkileşim halindedir. Her sağlık örgütü etrafına hizmet şeklinde çıktılar sunmaktadır. Çıktıların çevrede oluşturduğu olumlu ya da olumsuz reaksiyonları öğrenebilmek için etkin bir iletişim içinde olunması gerekir (Sözen, 2003: 29). İletişim bir duygu, düşünce ya da bilginin herhangi bir araç ile başkalarına iletilerek, yanıt verme, etkileme ya da tutum değişikliğine sebep olma sürecidir (Aydın ve Taş, 2013: 21). Demek oluyor ki hastane hastalar ile sağlik ocağı halk ile iyi bir diyalog kurmak mecburiyetindedir (Sözen, 2003: 29). İletişim kavramı sadece sağlık hizmeti üreten sağlık kurumları için değil, bütün kurumlar için eşdeğer öneme sahiptir. Sağlıklı iletişim kurmak ya da kurabilmek aynı zamanda iyi bir yönetimin anahtarıdır.

Çıktıları/hizmetleri daha verimli ve planlara uygun yapabilmek için ise, hem iki yönlü ve çok yönlü iletişimi hem de demokratik katılımı önemsemek gerektiğini belirten Sözen'e göre örgütler ihtiyaçları olan bilgileri örgüt içinden ve dışından edinirler. Edinmiş oldukları bu bilgiler ilgili birimlerde karara dönüşür. Bütün bu işlemler örgütteki kişiler tarafından yerine getirilir. Kişiler ve iletişim olmadan örgütün belirlemiş olduğu amacını gerçekleştirmesi düşünülemez. Bir Amaç ve etkin iletişim olmadan toplumun planlanmış ve belirlenmiş ihtiyaçlarına sağlık ocağının da hastanenin de cevap veremeyeceğini düşünen Sözen bu duruma şu örneği verir: Serviste hastaya ilişkin bilgilerin tam ve zamanında servis şefinin eline geçmediğini ya da sağlık ocağı doktorunun, ebenin mahalle gezileri hakkında bilgisinin olmadığını aklınıza getirin. O serviste veya sağlık ocağında verim ve başarı ümit edilemez 
(2003: 30). Dolayısıyla burada örgütün belirlenen bir amacının olması ve sağlıklı bir iletişimin önemi vurgulanmaktadır.

Sağlık Bakanlığı'nın Türkiye'de sağlık örgütlenmesinin iskeletini oluşturduğu söylenebilir. Nasıl ki iskelet sistemi canlıların hareket edebilmesini, yaşamak için gerekli olan faaliyetlerin yerine getirilmesini ve bu faaliyetlerin yerine getirilmesinde önemli rol alan organların ev sahipliğini yapıyorsa, Sağlık Bakanlığı'da sağlık hizmetlerinin hem oluşturulmasından hem de sunumunda aktif rol oynar. Bu nedenle gerek sağlık hizmetlerini üreten ve gerekse bu hizmetleri sunan sağlık örgütünün oluşturulması konusu hassas ve bir o kadar da önemlidir.

\subsubsection{Yönetme (Yöneltme)}

İki veya daha fazla (ya da bir insan tek başına) insan bir amaç doğrultusunda bir araya gelip bir grup oluşturduklarında, belirlenen amacı gerçekleştirebilmek için üyelerin beraber çalışmaları gerekir. Diğer bir ifadeyle iş bölümü gereklidir. İş bölümü varsa yönetimde gereklidir (Sözen, 2003: 2). Emir-kumanda etme, karar verme, yönlendirme gibi anlamlara da gelebilen yönetme, genel olarak örgütün amaçları doğrultusunda personeli ve diğer kaynakları sevk ve idare etmektir (Aydın, 2011: 60).

Yönlendirme (direction), üretimde kullanılacak kaynakların örgütün amacına uygun olarak, en etkin şekilde kullanılma çabası olarak tanımlanabilir. Bunun yalnızca emir vermek, bildirge ve yönerge yayınlamak ile temin edilemeyeceğini bilmek gerekir. Yönlendirmenin temelinde üretim ekibi üyelerinin kabiliyetlerini örgütün amacını gerçekleştirmek için seferber etmelerini temin etme durumu vardır. Çünkü çoğunlukla ekip üyelerinin kişisel amaçları ile örgütün amaçları örtüşmez. Örneğin, bir sağlık ocağı doktorunun amacı, koruyucu hekimlik hizmetlerini en yüksek seviyede devam ettirmek değil, bir an evvel asistanlık sınavına girip başarılı olmak olabilir. Bir sağlık bakanının amacı da bakanlık görevinde uzun zaman kalabilmek olabilir. İyi bir yönetici, örgütün amacını hizmeti üretenlere yani çalışanlara benimsetebilen kişidir. Ortaklaşa karar ve değerlendirme bu konuda etkili yollardan bir tanesidir. Bilgi verme, özendirme ve örgütün amacına hizmet eden çalışanlara ödül verilmesi de yönlendirme için etkili yöntemler arasında yer almaktadır (Fişek, 1983: 110).

Yöneltme'yi, mevcut olan maddi ve beşeri kaynakların amaçlar doğrultusunda harekete geçirilmesi faaliyeti olarak tanımlayan Çelik, yeterli sayıda çalışan ve araç gerecin temin edilmesinin amaçlara ulaşmak için yeterli olmadığı söyler. Bu nedenle Örgüte ait olan tüm 
kaynakların istenilen yönde kullanıldığından ve örgüt amaçlarına ulaşmaya yönelik olarak çalıştığından yöneticilerin emin olması gerekir. Yöneltme fonksiyonu; iletişim, güdüleme (motivasyon), liderlik gibi temel süreçler yanında insan unsuru ile ilgili bütün çalışmaları (çatışma yönetimi, davranış değiştirme vs.) içermektedir. Yönetici ise başkaları tarafından o konuma getirilmiş, başkaları adına çalışan, önceden belirlenmiş hedeflere ulaşmak için efor sarf eden, işleri planlayan, uygulatan ve aynı zamanda kontrolünü sağlayan kişidir (2012: 80-81). $\mathrm{Bu}$ doğrultuda iletişim, motivasyon ve liderlik kavramlarının yönetme fonksiyonun ayrılmaz bir parçası olduğu anlaşılmaktadır.

Motivasyon; insanları harekete geçiren ve başlatılan hareketlerin devam ettirilmesini sağlayan itici bir güç, bir kuvvet (Akçakaya, 2010: 315) anlamına gelmektedir. Ayrıca motivasyon, kişilerin belirli bir amaca ulaşmak için kendi istekleri ile davranmaları şeklinde tanımlanabilir. Bireylerin çalışma performanslarını artırma veya iş verimliliklerini yükseltme gibi öğelerin artırımını gerçekleştirmek için gerekli olan en önemli faktör olarak karşımıza gelmektedir (Işık vd; 2013: 77-78). Motivasyon, personelin hem seviyesini hem de ulaşılan hedeflerin kalitesini önemli oranda etkileyen bir faktördür. Yapılan araştırmalar, yüksek motivasyona sahip çalışanların işlerinde yeteneklerini \%80-90 oranında kullandıklarını göstermektedir. Motive olmamış çalışanlar ise yeteneklerini çalışmış oldukları işe tam olarak aktarmamaktadırlar (Çelik, 2012: 80).

Liderlik ise insanlara, yapmaları söylenen şeyleri yaptırmak için, onları bunun her şeyden evvel kendi fikirleri olduğuna inanmalarını sağlamaktır. Başka bir tanımla liderlik ya da önderlik, başka insanların enerjisini, kendi en üstün menfaatlerini temsil eden veya etmeyen bir amaç veya hedefe ulaşılması yönünde eyleme geçirme gücüdür (Aydın, 2015: 87).

Çă̆ımızda, kuruluşlar veya örgütler, her şeyden evvel insanlardan meydana gelen sosyal varlıklardır. Kuruluşların başında yer alan yöneticiler de, grup olarak bir araya gelmiş ve belli bir amaca ulaşmak için örgütlenmiş olan bu insanları, hedefe ulaşmak için, uyumlu bir biçimde ve iş birliği içinde, etkili ve verimli olarak yönetmek sorumluluğunda ve mecburiyetinde bulunan bireylerdir. Çünkü insan, örgütlerin ve yönetimin hammaddesidir. Dolayısıyla, insanı verimli bir şekilde yönetmek esastır. Bütünleşik yapı, çağdaş yönetimin en önemli niteliğidir. Bu demek oluyor ki, sistem yaklaşımıdır. Çünkü içinde bulunduğumuz çağda yönetim, çevredeki doğal, sosyal, siyasal, kültürel, ekonomik ve benzeri etkilerin tesiri altındadır. Çağdaş yönetici mevcut olan bu etkileri değerlendirmek ve dengelemek mecburiyetindedir (Aytürk, 1990: 2). 
Sağlık kurumlarının kar elde etme amaçları olmasa da, öteki işletmeler gibi toplumun sahip olduğu kıt kaynakları kullanmakta ve ekonomik ilkeler çerçevesinde, en azından toplumların sağlık hizmetlerine ayırmış olduğu kaynakları akılcı şekilde değerlendirmek mecburiyetindedirler. Kaynakların akılcı şekilde kullanılarak üretime dönüştürülmesi ve üretilen hizmetlerin topluma en ekonomik şekilde sunulması, sağlık kurumları yöneticilerinin sorumluluğundadır (Kavuncubaşı, 2002: 47).

Yönetimde belirli konumları ele geçirecek yöneticiler de aranacak özel nitelikler her kuruluşta ve her kadro da, görevin gereksinimlerine göre farkl1lık gösterir. Fakat her yöneticinin sahip olması gereken temel nitelikler vardır. Yönetimde, mevcut olan kaynaklar, olanaklar ve şartlar aynı olduğu halde, iyi ve nitelikli bir yöneticinin elinde başarılı olan bir kuruluş, tersi durumda başarısızlığa uğrar. Elde bulunan kaynaklar ve olanaklar aynı olduğu halde yönetimde ulaşılan sonuçlar, her zaman yöneticilerin kabiliyetlerine ve sahip oldukları niteliklere göre değişir. O yüzden bilgi, yetenek ve deneyim yöneticiliğin gerektirdiği temel niteliklerdir. Fakat her yöneticide ilk olarak aranılan temel nitelik yönetim bilgisi olmaktadır. Çünkü bütün yöneticilerin öncelikli olarak yönetimi bilmesi gerekmektedir ve her yöneticinin sevk ve idare yeteneği ve aynı zamanda yeterli tecrübesinin de bulunması gereklidir (Aytürk, 1990: 4).

Davranışlarını takımın amacına yönlendirmede çalışma yönergelerinin uygulanabilir olması da önem arz etmektedir. Bu anlamda hiç kimseye uygulanamayacak bir görev vermemek yönetimin esas kurullarındandır (Fişek, 1983: 110). Artık, yönetici unvanına sahip olmanın ve yönetici mevkiinde oturmanın her sözün dinleneceği ve verilen her emrin yerine getirileceği anlamını taşımadığını ifade eden Aytürk' e göre yönetici, ancak etkili ve verimli yönetimi sayesinde saygın duruma gelir ve başarı elde eder. Yine Aytürk'e göre; İçinde bulunulan çağ da sürekli olarak önemi artan ve içinde bulunulan çağın yapısını meydana getiren insancıllaşma, toplumsallaşma, demokratikleşme ve özgürleşme temayülleri, yönetimde de etkinliğini ortaya koymaktadır. Bu sebeple, çağdaş yöneticiler yönetimde insana değer veren, toplumcul, demokratik, özgürlükçü ve hoşgörülü olmak durumundadır. Artık yöneticilerin eski otoriteleri bulunmamaktadır. Çoğunluk, otoriter niteliğe sahip yöneticilerden hazzetmemektedir. Yöneticiler gerek astlarından gerekse toplumdan gerekli saygıyı ancak işte göstermiş oldukları tutumlarıyla, başarılı ve faydalı çalışmalarıyla sağlamak mecburiyetindedirler (1990: 2).

Günümüzde yönetim anlayışında bazı değişimler meydana gelmektedir. Bunların başında ise yönetici kavramının yerine lider kavramının gelmesi gerektiği ile ilgilidir. Çünkü yöneticiler genellikle şimdi ya da gelecekte olabilecek iş ve durumlara önceden belirlenen 
planlara göre kendilerini ve personelini hazırlarlar. Her şey çok hızlı değiştiğinden hazırlanan bu planların uygulanabilirliği ya çok az ya da hiç kalmamaktadır. Oysa liderlik her şart ve durumda olaya çözüm getirmek üzere kendilerini ve personelini harekete geçirmek üzere görev yapmak üzerine kuruludur. Özellikle sağlık yönetimi de liderlik fonksiyonunun yer aldığı bir yönetim tarzı benimsenerek yürütülmelidir. Çünkü değişen çevre şartlarına sağlık yönetimini gerçekleştiren kişinin hem kendisini hem de başında bulunduğu sağlik örgütünü adapte edebilmesi, hızlı ve etkili kararlar alarak geleceği öngörmesi gerekir.

Liderlerin personelin motivasyonunu dikkate alarak işlerini yapmalarını sağlamaları gerektiği, onları yönetici kavramından farklı kılan diğer bir özellik olarak karşımıza çıkar. Lider ve başında bulunduğu kurumu, motivasyon olmaksızın hareket edemez. Çünkü motivasyon eksik olursa ya da hiç olmazsa, hangi iş olursa olsun etkin ve verimli şekilde yapılamaz. Özellikle sağlık sektöründe sağlık örgütünü oluşturan personel için motivasyon çok önemlidir. Çünkü amaç insanı/insanları sağlığına kavuşturmaktır. Bu ise ancak yaptıkları işi seven sağlık örgütü çalışanları tarafindan yerine getirilebilir. Motivasyon ise iyi bir liderin etkin bir yönetim sergileyebilmesi ile mümkündür.

\subsubsection{Koordinasyon (eşgüdüm)}

Eylem birliği anlamına gelen eşgüdüm (Ergun ve Polatoğlu, 1988: 101-102), bugünün karmaşı örgütleri için hayati derecede önemlidir (Şahin, 2015: 249). Eşgüdüm, bir örgütteki birimlerin organizasyonel amaçları gerçekleştirmek için aynı konuda çalışan diğer kuruluşlarla ve birimlerle uyumlu olarak işletilip işbirliğinin sağlanması sürecidir. Örgütün kendiside aynı zaman da bir eşgüdüm sağlama aracıdır (Parlak, 2013: 208).

Karmaşık bir işletmede ürün ve hizmet üretimi için iş bölümü ne kadar mecburi ise üretim takımı içinde türlü görevleri olan kişiler arasında eşgüdümü gerçekleştirmek de o kadar mecburidir. Bu yol vasıtasıyla parçalara ayrılan işin parçalarının kaynaşması ve bütünleşmesi mümkündür (Fişek, 1983: 110). Elde bulunan kaynakların boş yere harcanmasına engel olmak, üretilen hizmetlerin maliyet/etkinlik oranını yükselterek verimliliği artırmak amacıyla personel arasında uyum/ahenk gerçekleştirilmelidir. Eşgüdüm, özellikle sağlık hizmetlerinde çok önemli yere sahiptir. Çünkü hastanın yeniden sağlığını kazanması, sağlıklı olanlarında hastalıklardan korunarak sağlıklarının yükseltilmesi, başkalarının gayret ve katkılarının birleşmesiyle mümkün olmaktadır (Sözen, 2003: 37). 
Eşgüdüm, yönetsel etkinliğin ön şartı ve aynı zamanda temel aracıdır (Fişek, 1975: 237). Eşgüdüm, örgütlerdeki iş bölümü, hacim açısından büyüme ve işleyişin kompleks bir nitelik göstermesinin ortaya çıkardığı bir problemdir. Eşgüdüm, yönetsel yapı bünyesindeki türlü eylemlerin bütünleştirilmesi çabası anlamına gelmektedir (Eryılmaz, 2009: 4). Eşgüdümü gerçekleştirme görevi, büyük oranda, hiyerarşide üst derece de bulunan yöneticinin, takım liderinin görevidir. Bu türlü enstrüman çalan bir orkestranın bir yapıtı başarılı bir şekilde yorumlamasında orkestra şefinin üstlenmiş olduğu role benzetilebilir (Fişek, 1983: 110).

Sağlık kurum ve kuruluşlarında eşgüdümü sağlamanın iki temel unsuru bulunmaktadır. İlki, her üyenin görev ve sorumluluklarının yazılı olduğu yönergelerin hazırlanması ve bu yönergelerde kimlerin kimlerle hangi iş birliği içinde olacağı yazılı olmalıdır. Diğeri ise, takım üyeleri arasında ve takımlarla sürekli kesintisiz iletişimin kurulmasıdır. Bu iki yöntemin başarılı bir şekilde uygulanmasını ilk olarak takım liderinin, daha sonra da bütün takım üyelerinin görevi olarak açıklayan Sözen, eşgüdümü olumsuz yönde etkileyen unsurları şöyle sayar: Yönetimde; yatay iletişimin zayıf olması, örgütün çok büyük ya da geniş olması, uzmanlaşmanın çok olması, eşit düzeydeki yöneticilerin negatif davranışları, eşgüdüme katılan birimlerin görevlerini tam olarak yerine getirmemeleri ve sorumluluk üstlenmemeleri, eşgüdümden sorumlu olan yöneticinin ilgisizliği (2003: 37-38). Bu olumsuzlukların yanı sıra eşgüdümü kolaylaştıran unsurlarda söz konusudur. Örneğin haberleşme gibi.

Haberleşmenin iyi olması eşgüdümü kolaylaştırır. İnsanın bir işte gerektiğinde ayarlamalar yapabilmesi için, o işin plana uygun olarak yürüyüp yürümediğini bilmesi gerekir. İşin içinde oluşturduğu koşullar ve yapılması düşünülen değişiklikler hakkında bilgi verme, gelecek için planlar hazırlanması açısından da büyük önem arz eder (Parlak, 2013: 211).

Koordinasyon, diğer bir ifadeyle eşgüdüm çeşitli yöntemlerle gerçekleştirilebilir. Bunlar; hiyerarşiye dayanan, inandırıcı, komiteler yoluyla, yatay ve dikey, yapı ve görevle ilgili ve son olarak iç ve dış koordinasyon olmak üzere altı grupta toplanır (Aydın, 2011: 73).

\subsubsection{Denetim (kontrol)}

Hiyerarşik üstler tarafından verilen kararların astlar tarafından yerine getirilip getirilmediğinin sonsuza kadar izlenmesi, hem etkin örgütsel işleyişin temel yaptırım ve inancası, hem de herhangi bir anda örgütün nasıl bir durumda olduğunun başlıca göstergesidir. $\mathrm{Bu}$ görüşe göre denetimi, örgüt tarafından benimsenen amaçların veya üstlenilen görevlerin 
eksiksiz, verimli ve zamanında gerçekleşip gerçekleşmediğinin hiyerarşi içinde ve yaptırımlı şekilde izlenmesi olarak açıklanabilir (Fişek, 1975: 238).

Denetim, ulaşılan sonuçlarla istenen sonuçların (amaçlar) karşılaştırılması, gelinen durumun değerlendirilmesi faaliyetlerini içinde barındırmaktadır. Yöneticiler istenilen ile ulaşılan sonuçlar arasında bir uyumsuzluk söz konusu olduğunda düzeltici eylemler gerçekleştirirler. Denetim faaliyeti, başarı standartlarının saptanması, ulaşılan sonuçların standartlar ile karşılaştırılması ve varsa eğer sapmaların belirlenerek gerekli tedbirlerin alınması faaliyetlerini içinde bulundurmaktadır. Görüldüğü üzere denetim sürecinde, sadece kurumsal etkinlik seviyesi, yani planlama aşamasında belirlenen amaçların başarılamamasının sebepleri araştırılmakta ve başarısızlığa neden olan unsurların yok edilmesine (düzeltici eylemler) çalışılmaktadır (Kavuncubaşı, 2002: 50).

Denetim kelimesi bazı insanlarda katı olmayı, kurallar koymayı, bürokratik ilkelere uyup otoriter davranmayı akla getirebilmektedir. Fakat denetim faaliyeti ile bu sayılanların yapılmasına ihtiyaç olmayabilir. Yöneticilerin, insan gücü de dahil olmak üzere tüm kaynaklarını etkili bir biçimde bir araya getirme, gerçekleştirilen eylemlerin hedeflere yönelik olduğundan emin olma gibi bir sorumluluğu bulunmaktadır. Çünkü yöneticilerin her şeyi yapma gibi ne bir sorumlulukları ne de bir zamanları bulunmamaktadır. Bunun yerine gerçekleştirilecek işleri saptama, bu işleri gruplar arasında dağıtma ve ne yapıldığını devamlı olarak değerlendirme sorumluluğu bulunmaktadır. Bir yöneticinin, örgüt içinde gerçekleştirilen işleri denetleyebilmesi için ilk olarak örgüt amacının ve bu amacı gerçekleştirebilmek için hangi tür işlemlerin, nasıl yapılması gerektiğinin belirlenmesi ve bir plana bağlanması gerekir. $\mathrm{Bu}$ süreçte, gerçekleştirilen çalışmaları izleyerek plan ve programlarla kıyaslama yapılmasına müsaade edecek etkili bir bilgi toplama merkezine olan gereksinim açık bir gerçektir. Bir denetleme süreci dört önemli aşamayı içinde barındırmaktadır. Bunlar; gerçekleştirilen çalışmaların belirlenmesi ve her çalışmanın başarı standartlarının ortaya konulması, gerçekleşen durumun ölçülmesi, standartlar ile gerçekleşen durumun kıyaslanması, standartlardan sapma varsa düzeltici önlemlerin alınması aşamalarıdır (Çelik, 2012: 81).

Bir ebe veya hemşire denetleneceği zaman ilk olarak standartlar belirlenir. Ebe veya hemşireden beklenen tutumlar, göreviyle ilgili yapması gerekenler tayin edilir. Bu standartlar hem elde edilebilir hem de kabul edilebilir olmalıdır. Ayrıca mantıklı olmalıdır. Ülkenin ve görev yapılan mekânın özelliği göz önünde bulundurularak, denetlenenlerle beraber bu standartların hazırlanması gerekir. İlk olarak standartlar belirlenir, daha sonra uygulama yapılır, 
iş-eylem gerçekleştirilir, uygulama sonucundaki eksiklikler belirlenerek bu eksikliklerin sebepleri araştırılır. Son olarak, düzeltme işlemleri yapılarak geri bildirimde bulunulur (Sözen, 2003: 40). Sağlık kuruluşlarının denetiminde çeşitli denetim türleri mevcuttur.

Tengilimoğlu vd. sağlık kuruluşlarının denetiminde üç çeşit denetim türünden bahseder. Bunlar; iç denetim, dış denetim ve kamuoyu denetimidir. İç denetim, daha çok sağlık kuruluşlarının gerçekleştirmiş oldukları çalışmaları kendi iç denetim mekanizmaları ve standartlarla denetlenmesini kapsamaktadır. Hastanelerde iç denetim çalışmaları çoğunlukla komiteler tarafindan yerine getirilmektedir. Bu komitelerden bazıları; Tıp hizmetleri yürütme kurulu, Tıbbi soruşturma komitesi, Tıbbi kayıt komitesi, Doku komitesi, Etik komitesi, Enfeksiyon komitesi, Kan ve kan ürünleri komitesi, Kan ve kan ürünleri komitesi, Sağlık standartlarını gözden geçirme komitesi, Kullanım komitesi, Koordinasyon komitesi olarak ifade edilebilir. Bunların haricinde daha özellikli olan yangın, hijyen, radyasyon ve tıbbi alet ve ilaç denetimlerini yerine getiren komiteler de bulunmaktadır. Ayrıca, dış denetim mekanizması olarak kamuoyu ve meslek odalarının da önemli ölçüde dış denetim faaliyeti vardır. Eğer hastanenin ISO belgesi var ise ya da akredite olmuş ise belge veren kuruluşlarda periyodik denetimler gerçekleştirmektedir (2014: 64-65). Bunların yanı sıra denetleme işlevinin yeteri kadar yerine getirilemediği durumlarda söz konu olabilmektedir. Bu duruma Tengilimoğlu vd. şu örneği verir: Hastanelerin genel olarak yayınlanmış düzenlemelere uygunluğunu izlemek amacıyla yasalarla tayin edilmiş inceleme mekanizmaları vardır. Örnek olarak Sağlık Bakanlığı denetim elemanlarınca hastanelerin gerçekleştirmiş oldukları faaliyetler yasalara uygunluğu bakımından denetime tabii tutulmaktadır. Tıbbi anlamda ise gerçekleştirilen işlemlerin doğruluğunu denetleme yeteri kadar gerçekleştirilememektedir (2014: 65).

Sağlık hizmetlerinde denetim faaliyetinin hayati öneme sahip olduğunu, çünkü yapılacak herhangi bir hatanın insan hayatının kaybına neden olabileceğini belirten Tengilimoğlu vd.,bu yüzden her aşamada denetimin gerekli olduğunu savunur. Yine Tengilimoğlu vd. 'ne göre klasik yaklaşım içerisinde gerçekleştirilecek denetimler performans ölçümünden öteye gitmez. Bu sebeple sağlık sektöründe toplam kalite yönetim anlayışının kabul edildiği kalite denetimi kabullenilmelidir (2014: 64). Buradan sağlık yönetiminin toplam kalite yönetimi anlayışı ile ilgili olduğu sonucuna da varılmaktadır.

Sonuç olarak belirtmek gerekirse; her bir fonksiyon kendi içerisinde planlama, örgütlenme, yönetme, koordinasyon ve denetleme fonksiyonlarını ya da diğer bir ifadeyle yönetimin beş temel fonksiyonunu barındırmaktadır. Örneğin planlama fonksiyonu içerisinde 
örgütlenme, yönetme, koordinasyon ve denetleme fonksiyonları yer almaktadır. Bu nedenle her bir fonksiyon diğerinden bağımsız olarak düşünülemez. Yönetim sürecinin eksiksiz tamamlanması için her bir fonksiyonun tam ve eksiksiz olarak yerine getirilmesi gerekir. Ayrıca yönetimin temel fonksiyonlarını yerine getirmede iletişim, motivasyon ve liderlik/yönetici kavramlarının öne çıktığı görülmektedir.

\section{SAĞLIK YÖNETIMMINDE ÇAĞDAŞ YÖNETIM YAKLAŞIMLARI}

Günümüzde çağdaş yönetim yaklaşımları olarak adlandırılan ve yönetimin gelişmesine katkıda bulunan yeni yaklaşımlar bulunmaktadır. Bunlar, toplam kalite yönetimi, değişim yönetimi, stratejik yönetim, zaman yönetimi, stres yönetimi, performans yönetimi, kriz yönetimi, risk yönetimi çatışma yönetimi, kariyer yönetimi, süreç yönetimi, toplantı yönetimi, bilgi yönetimi, kalabalık yönetimi olarak sayılabilir. $\mathrm{Bu}$ yaklaşımların hepsi bir diğeri ile bağlantılı olup ortak amaçları yönetimde verimliliği ve etkinliği artırmak diğer bir ifadeyle yönetim sürecinin başarılı bir şekilde gerçekleştirilmesini mümkün kılmaktır. İster kamu ister özel sektör olsun her yönetimde uygulanması gereken çağdaş yönetim yaklaşımları, sağlık yönetiminde de uygulanmalıdır. Çünkü yönetim insan ile ilgilidir. Dolayısıyla söz konusu yaklaşımların sağlık sektöründe uygulandığı taktirde sağlık yönetiminde de verimliği yükseltmede ve başarıyı artırma da katkı sağlayacağı açıktır. Çağdaş yönetim yaklaşımlarını temsil etmesi bakımından sağlık sektörü ile ilişkili olduğu düşünülen bu teorilerden sırasıyla, toplam kalite yönetimi, performans yönetimi ve toplantı yönetimi aşağıda açıklanacaktır.

\subsection{Toplam Kalite Yönetimi}

Küreselleşme kavramıyla beraber bütün dünyada, kamu özel ayrımı yapılmaksızın bütün örgütlerde yaşanan rekabet, yenilik, yaratıcılık alanındaki gelişmeler, tüm örgütleri ve kuruluşları toplam kalite yaklaşımını benimsemeye zorlamıştır. Günümüzde hızı bir şekilde yaygın hale gelen kalite hareketi, pek çok kavramla ve oluşumla ilişkilendirilmeye çalışılmaktadır. Ancak hareketin özünde kalite felsefesi vardır (Tortop vd., 2010: 241).

Çok açık ve net olarak tanımlanamayan kalite kavramını, organizasyon ve yönetim bilimi içerisinde çeşitli düşünürler ve uzmanlar çok farklı şekillerde tanımlamaktadırlar (Aktan, 1999: 70). Literatürde yer alan bazı tanımlara göre kalite; Bir mal ya da hizmetin özelliklerinin, mevcut ya da ileride gerek duyabilecek alıcı (müşteri-vatandaş) ihtiyaçlarını karşılayabilme yeterliliği (Akgül ve Vural, 1999: 192); Mükemmellik veya uygunluk standardı veya ölçüsüdür 
(Yatkın, 2004: 22). Ayrıca kalite, bir hayat felsefesi, yönetim tarzı, mutlu vatandaş, israfin önlenmesi, daimi bir iyileştirme süreci (Akgül, 1999: 37) olarak ifade edilir.

Toplam kalite yönetimi ise, ürün ve hizmet kalitesini ve daha geniş anlamda ise örgüt kalitesini sürekli olarak iyileştirmek için organizasyonda yapılması gereken bütün çabaları ifade eder. Kalite yönetimi kelimelerinin başına toplam kelimesinin eklenmesinin sebebi organizasyonel performansı artıracak bütün alanlarda kalite geliştirilmesinin amaçlanmasıdır (Aktan, 1999: 72). Toplam kalite yönetimi bir kuruma uygulandığında, yöneticiler ve işgörenler dahil olmak üzere herkesi ihtiva eden, sürekli iyileştirme faaliyetlerinin gereğini öngören yaklaşımdır (Akgül ve Vural, 1999: 192). Ayrıca toplam kalite yönetimi, iç ve dış müşteri beklentilerinin aşılmasını temel amaç olarak alan, çalışanlarının bilgilendirilip yetkilendirilmesini ve takım çalışmaları ile bütün süreçlerin sürekli olarak iyileştirilmesini hedefleyen bir yönetim felsefesi (Yatkın, 2004: 22); bir kuruluştaki bütün faaliyetlerin sürekli iyileştirilmesi ve örgütteki bütün çalışanların aktif katılımıyla, çalışanların, müşterilerin ve hedef kitlenin memnun edilerek, etkinliğe ve verimliliğe ulaşılması sürecidir (Tortop vd., 2010: 241). Temelinde "standartlara uygunluk" bulunan toplamkalite yönetimi, "kaliteli ürün üretme" düşüncesi üzerine odaklanmıştır (Saruhan ve Yıldız, 2013: 205).

Toplam kalite yönetimi, işletme çalışanlarının kaliteli mal ve/veya hizmet üretmek olan ortak bir amacı benimsemelerini ve bu amaç doğrultusunda hareket etmelerini gerektirmektedir. Günümüzde toplam kalite yönetimini benimseyen işletmeler rekabet üstünlüğü sağlayarak kurumsal performans hedeflerine daha kolay ulaşabilmektedir. Toplam kalite yönetimi, sadece üretilen mal ve/veya hizmetlerin değil, aynı zamanda örgütün kalitesinin artırılmasıdır. Örgütün kalitesinin artırılması ise; üretilen ürün ve/veya hizmetlerin kalitesinden, bu ürün ve/veya hizmetlerin üretildiği süreçlerin kalitesine, çalışanların motivasyonu ve ödüllendirilmesine kadar her alanda kalitenin artırılmasıdır (Saruhan ve Yıldız, 2013: 205-206). Burada sözü geçen müşteri kavramı işletmeler için kullanılmakta fakat günümüzde kamu yönetimi açısından bakıldığında da değişen yönetim anlayışıyla birlikte vatandaşa/halka müşteri gözüyle bakıldığı söylenebilir. O nedenledir ki ister kamu yönetiminde ister işletme yönetiminde olsun üretilen hizmet insan odaklı olacaktır.

Toplam kalite yönetiminin temelinde "hataları ayıklamak" yerine "hata yapmamak" yaklaşımı bulunur. Önlemeye yönelik yaklaşımın genel bir anlatımı planlamanın doğru yapılması şeklinde özetlenebilir. Her yönü ile düşünülmüş, kapsamlı bir planlama çalışması ile sonradan oluşabilecek hataların büyük bir kısmı önlenebilir. Hataları önlemede planlama 
öncelikli unsurdur. Sorunlar meydana gelmeden çözümleri oluşturmak ve ürünlerin ve hizmetlerin yapısında tasarım yoluyla üstünlük oluşturmak gerekmektedir (Tortop vd., 2010: 246).

Toplam kalite yönetimi, yapılan işin her aşamasında kalitenin artırılmasını hedefler. Bu, yalnızca üretilen ürün ya da hizmetin değil, aynı zamanda ürün ya da hizmeti üreten (örgüt personeli) ve ürün ya da hizmeti alan (müşteri) kişilerin kalitesinin düşünülmesini (yani arz ve talep kalitesi) ve hatta kaliteyi bir hayat tarzı olarak benimsemelerini de kapsar. Dolayısıyla burada insana verilen değer ön plana çıkmaktadır (Aydın, 1999: 15; Aydın, 2004: 95).

Toplam kalite yönetiminde üretilen mal ve hizmetlerin niteliğinde sürekli iyileştirme öngörülmektedir. Söz konusu iyileştirmenin başarılabilmesi için ise, işletmelerde yönetimin ve çalışanların kalitesi gündeme gelmektedir. Her ne kadar müşteri istekleri ön plana alınmış olursa olsun, belirli hedefler geliştirilirse geliştirilsin, eğer çalışanlar ve yöneticiler belli bir kalitede değillerse, yapılan çalışmalar belli bir düzeyden öteye gidemez. Bu nedenle diğer hususlar kadar, yönetim ve çalışanların kalitesi de çok önemlidir (Paksoy, 2007: 569). Toplam kalite yönetiminde hedeflenen başarı seviyesine ulaşılabilmesi için uygulanacak olan kalite programlarına herkes katılım sağlamalıdır. En alt kademedeki çalışanlardan, en üst düzey bulunan yöneticilere, tedarikçilerden, üretim sürecinde yer alan bütün çalışanlara kadar herkesin hataları önlemek ve kaliteye ulaşmak için çaba göstermesi zorunludur (Koç ve Topaloğlu, 2012: 135). Bu anlayışa göre aynı zamanda üretimin müşterinin veya hizmeti alanın tercihleri ve beklentileri yönünde olması, bunu yaparken de çalışanlarında çalışma koşullarının iyi olması veya kaliteli olması gerekmektedir (Aydın, 2011: 152).

Toplam kalite yönetiminde, kalite kavramı işletmenin bütün bölümlerine yayılmıştır. Diğer bir ifadeyle, bu yönetim uygulamasında kaliteye hizmet etmek, bütün örgüt üyelerinin temel düşüncesidir. Dolayısıyla, üretim sürecinin herhangi bir sürecinde ortaya çıkabilecek hatalar ve fireler en aza indirgenebilecektir. Ayrıca; stoklar düşürülebilecek, zamandan tasarruf sağlanabilecek ve maliyetler aşağıya çekilebilecektir. Aynı zamanda toplam kalite yönetiminin önemli üstünlüklerinden birisi olan müşteri odaklılık doğrultusunda, müşteri talep ve beklentileri zamanında ve istenildiği gibi karşılanmış olacaktır. Ürünle ilgili hataların sebeplerinin tespit edilmesi ve sıfırlanabilmesi için gerekli tedbirlerin alınması, sürekli gelişmeye katkıda bulunacaktır. Toplam kalite yönetiminin uygulamaları doğrultusunda oluşan organizasyon yapısında, kalite sorumlulukları açıkça tanımlanmalıdır. Böyle bir organizasyon 
yapısı; bir taraftan hataların önlenmesine, diğer taraftan örgüt üyelerinin sürekli kendilerini geliştirebilmelerine katkıda bulunabilecektir (Saruhan ve Yıldız, 2013: 206).

$\mathrm{Bu}$ açıklamalar dikkate alındığında kalitenin sağlık yönetiminin tamamını kapsaması gerekir. Sağlık hizmetlerini sunan ve üreten örgütten (personelden) bu hizmeti alan hastalara kadar her alanda kalite belirgin şekilde görülmelidir. Bu ise kalite bilincinin oluşturulması ile mümkün hale gelir. Toplam kalite yönetimi anlayışının sağlık sektöründe titizlikle uygulanması halinde ise, vatandaş/müşteri ya da diğer bir ifadeyle insan odakl1, değișen şartlara kolayca uyum sağlayabilen ve dolayısıyla kendisini sürekli olarak revize eden, değişime direnmeyen aksine adapte olmaya çalışan, demokratik, uyumlu, insan haklarını gözeten dolayısıyla insana saygı duyan bir yönetim anlayışı gelişmiş olacaktır. Bunun doğal bir sonucu olarak ise, sağlık yönetiminde mevcut bazı köklü sorunlarında önüne geçilmiş olacaktır.

Toplam kalite yönetimini organizasyonlarda 'kalite'nin artırılmasını amaçlayan bir yönetim felsefesi olarak ifade eden Aktan, bu yönetim anlayışında hedefin, müşterilerin istek ve beklentileri doğrultusunda ürün ve hizmetlerin kalitesinin yükseltilmesi ve verimliliğinin artırılması olduğunu söyler. Toplam kalite felsefesinde kalite ve verimliliğin artırılması için ise çalışanların memnuniyeti, motivasyonu ve ödüllendirilmesi, performans değerlendirme ve ölçme yöntemlerinin kullanılması, organizasyondaki hataların ve yanlışların ortadan kaldırılması, ekip çalışmasına ağırlık verilmesi, başarılı organizasyonların tecrübelerinden yararlanılması, stratejik planlama yapılması ve buna benzer hedefler üzerinde durulduğunu ifade eder (2005: 67).

Toplam kalite yönetiminin; insana değer veren bir yaklaşım olması, sürekli iyileştirme çabasının olması, organizasyonun sadece belli bir alanında değil tamamında kaliteye odaklanması, sürekli gelişmeye önem vermesi ve temelinde bu düşüncenin yer alması, değişime açık bir yönetim tarzına sahip olması, beklentiyi sürekli olarak aşması veya aşma isteği, ürün ve hizmeti üreten ve bu ürün ve hizmetten fayda sağlayan bireylerin memnuniyetini gözetmesi ve hata ayıklama yerine hata yapmama prensibine dayanması toplam kalite yönetiminin sağlık yönetiminde uygulanması gerektiğini ifade eder. Ayrıca performans ölçme ve değerlendirme yöntemlerinin kullanılması toplam kalite yönetiminin performans yönetimi ile de ilgili bir yönetim anlayışı olduğunu gösterir. 


\subsection{Performans Yönetimi}

Çalışanların başarılarının yönetilmesi ya da kontrol edilmesi veya başarısızlık sorununun önlenmesi ya da giderilmesi hususunda öteden beri performans ölçme ve değerlendirme kavramı kullanıldı. Ancak günümüzde performans ölçme ve değerlendirme kavramı yerine daha geniş anlamda kullanılan performans yönetimi kavramının geçerli olduğu kabul edilmektedir. Günümüzde kilit kavram performans yönetimidir. Bir anlamda performansın nasıl tanımlanacağ1 ve kuruluşun yararına kullanılacağ 1 ile beklenen performans düzeyine ulaşma sürecinin nasıl yönetileceği konuları önem kazanmıştır. Dolayısıyla, bireysel de olsa performans değerlendirme süreci örgütsel bir boyut kazanmış ve kuruluşun stratejik amaçları, örgütsel misyon ile ilişkilendirilmiştir (Aydın, 2011: 182).

İngilizce kaynaklı olup artık Türkçeleşmiş ve bununla birlikte yaygın bir kullanıma sahip olan Performans sözcüğü; herhangi bir işin, hizmetin veya malın yerine getirilmesi anlamına gelmektedir. Kamu sektörü açısından ise performans; kamu yönetiminin halka sunmayı üstlenip amaçladığı mal ve hizmetleri yerine getirilmesidir. Bu mal ve hizmetlerin yaptırılması ise, yönetim faaliyetini oluşturur (Çevik, 2001: 154).

Aslında bir yönüyle performans yönetimi gerçekleştirilen işin ne kadar bir örgütün amaç ve hedeflerine göre gerçekleştirilip gerçekleştirilmediğinin ölçülüp değerlendirilmesi konusu ile ilgilenir. Kural olarak her kamu kuruluşunun vatandaşa karşı; paranın kurallara uygun bir şekilde, görüş birliğine varılan hizmetler için harcanıp harcanmadığı; kaynakların verimli bir biçimde kullanılıp kullanılmadığı ve son olarak amaçlanan sonuçlara endeksli çalışmanın yapılıp yapılmadığına dair sorumluluğu bulunmaktadır (Çevik, 2001: 156).

Performans yönetiminin, kamu örgütleri ve personelinin daha kaliteli hizmet üretmelerini ve sunmalarını, dolayısıyla kamu yönetiminin daha etkin ve verimli olmasını sağladığı ileri sürülür (Aydın, 2015: 200). Ancak söz konusu yaklaşımının etkin ve verimli bir yönetim anlayışını geliştirmek amacını gerçekleştirebilmesi için, performans değerlendirme işleminin sağlıklı bir şekilde gerçekleştirilmesi gerekir. Söz konusu değerlendirmede kullanılan ölçütler (zaman, emek, liyakat vs) iyi analiz edilmeli, bir kurumun hiç olmayan başarısını sanki varmış gibi göstermeye çalışılmamalıdır. Özellikle sağlık sektöründe performans değerlendirme çalışmalarının sonuçları üzerinde önemle durulmalıdır.

Çalışanlarının başarılarının yönetilmesi ya da kontrol edilmesi konusunda günümüzde geçerli kavram "performans ölçme ve değerlendirme” değil “performans yönetimi” dir. Ancak 
performans yönetimi konusunda bir diğer önemli husus da performans ölçme ve değerlendirme konusudur. Performans yönetimi yapılan işin ne kadar bir örgütün amaç ve hedeflerine göre gerçekleştirilip gerçekleştirilmediğinin ölçülüp değerlendirilmesi konusunu inceler. Buradan, yönetimde insan unsurunun (personelin) performansının yönetilmesi ve değerlendirilmesinin yönetimde ne kadar önemli olduğu anlaşılmaktadır. Çünkü insan olmadan yönetimin amaçlarının gerçekleştirilmesi mümkün değildir (Aydın, 2011: 183).

Performans değerlendirmenin amacı; örgütteki çalışanların iyiden kötüye doğru sıralanması değil; örgütsel amaçların astlar tarafından öncelikle anlaşılma ve benimsenme derecesinin ortaya çıkarılması, amaçların herkes tarafından asgari düzeyde yerine getirilmesinin temin edilmesi ve herkesin mutlu olduğu dinamik çalışma ortamının devamlı muhafaza edilmesidir (Tengilimoğlu vd., 2014: 392).

Yönetimde gerçek anlamda bir performans yönetimi yaklaşımından bahsedilebilmesi için, ön koşul olarak klasik bir performans ölçme ve değerlendirmenin gerektiği söylenebilir (Aydın, 2011: 186). Etkin yöneticilerin genellikle kendilerine özgü performans değerlendirme biçimleri vardır (Drucker ve Macıarıello, 2005: 274).

Tengilimoğlu vd.'ne göre, organizasyonlarda performans değerlendirme yöntemleri organizasyonlar gibi sürekli değişim ve gelişim içindedirler. Fakat hangi yöntem kullanılırsa kullanılsın performans değerlendirme sisteminin başarıya ulaşabilmesi için ilk olarak görev ve iş analizinin yapılması, iş ve görevlerin tanımlanmış olması şarttır. Bunlarla beraber performans değerlemenin gerçekleştirilebilmesi için; değerlendirme kriterleri nedir? Hangi standartlarla değerlendirme yapılacak? Değerlendirme hangi aralıklarla gerçekleşecek? Değerlendirmeyi kim ya da kimler yapacak? Sorularının cevaplanması ve değerlendirme yapacak kişilerin eğitimi belirlenmiş olmalıdır (2014: 395).

Performans değerlemesi kısaca; işgörenin iş tanımı çerçevesinde yapmakla yükümlü olduğu iş ve görevlerini planlanan zamanda gerçekleştirme düzeyinin belirlenmesi şeklinde ifade edilebilir. Diğer taraftan daha genel bir yaklaşımla; işgörenin içinde bulunduğu örgütün amaçlarını gerçekleştirmek için örgütteki tutum ve davranışlarının, iş süreçlerindeki gayret ve çabalarının, ortaya çıkan sonuçlar üzerindeki etkinlik ve eksikliklerinin belirlenmesi süreci şeklinde tanımlanabilir (Koç ve Topaloğlu, 2012: 299). Diğer bir ifadeyle performans değerleme; belirli bir görev ve iş tanımı kapsamında bireyin bu iş görev tanımını ne düzeyde 
gerçekleştirdiğinin belirlenmesi çabası ve çalışanın tanımlanmış olan görevlerini belirli zaman dilimi içinde gerçekleştirme düzeyinin belirlenmesidir (Tengilimoğlu vd., 2014: 390-391).

Personelin performansının, gerçekleştirilmesi planlanan şeylerden ne kadarının başarıldığı ile ölçülmesi gerekir. Yönetici elinde bulunan mevcut insan kaynağı ile kendisinden beklenen sonuçları almak için vardır. Her ne kadar yönetici para, zaman ve malzeme gibi unsurları yönetmek ve kontrol etmekle görevli ise de, görevini daha çok elindeki insan unsuru aracılığıyla yerine getirir. Dolayısıyla yönetici mevcut personelin verimliliğini ve etkinliğini artırmaya, yani performansını yükseltmeye çalışmak durumundadır. Personelin performansı, aynı zamanda yöneticinin kendi performansının derecesini gösterir. Performans değerlendirmenin örgüte, yöneticiye ve çalışana yönelik çok sayıda yararı olabilir. Örneğin performansı değerlendirme, bütün örgütün, birimlerin ve bireyin performansının iyileştirilmesini sağlar ve örgüt içi ilişkileri iyi duruma getirir, var olan ve potansiyel sorunların bilinmesini sağlar ve performans ve başarı için geleceğe yönelik iyi planlar yapmayı kolaylaştırır. Buradan, aslında performans ölçme ve değerlendirme yapmanın iyi bir performans yönetimine yardımcı olduğu sonucuna ulaşılmaktadır (Aydın, 2011: 185-186).

Performans yönetimi ve motivasyon kavramları birbiri ile ilgili kavramlardır. Motivasyonun amacı bireylerin davranışlarını etkilemek ve bu etki doğrultusunda onları belirli bir harekete ya da hedefe yönlendirmektir. Performans yönetiminin amacı ise, çalışanların görevlerinin gerektirdiği doğrultuda yetkinliklerinin ve belirli konularda kendileri için oluşturulan hedefi gerçekleştirmelerini ölçmek suretiyle verimliliklerini ölçmek ve arttırmaktır. Performans yönetimi, bir örgütte insan kaynaklarının, örgüte olan katkıyı artıracak biçimde, sosyal ve etik ilkelere de uyularak yönetilmesidir (Tengilimoğlu vd., 2014: 389). Performans yönetiminin bir kuruluşun varlığını başarılı bir biçimde devam ettirebilmesinde temel unsurlardan biri olduğu vurgulanır. Bireysel performans yönetimi, kuruluşun yönetici ve yönetileni ile bütün elemanlarının stratejik amaçlar doğrultusunda ürün ve hizmet üretimlerini ve davranışlar sergilemelerini sağlama sürecidir (Aydın, 2011: 183).

En az toplam kalite yönetimi yaklaşımı kadar kamu özel fark etmeksizin tüm kurumlarını yakından ilgilendiren ve etkileyen diğer bir çağdaş yönetim yaklaşımı olan performans yönetimi, Son yıllarda çok duymaya alıştı̆̆ımız kavram, sağlık sektöründe de en gözde yerini almış durumdadır. Performans değerlendirmesi dolayısıyla performans yönetimi son yıllarda büyük bir değişim ve dönüşümün yaşandığı sağlık sektöründe de uygulanmaktadır. Örneğin belli bir dönem faaliyet gösteren Türkiye Kamu Hastaneleri Kurumu ve İl Kamu 
Hastaneleri Birliklerinin başında bulunan yöneticilerin yılsonunda performans değerlendirmeleri yapılarak performanslarına göre notlar veriliyordu ve yöneticilerin aldıkları puana göre görevlerini devam ettirip ettirmeyecekleri belirleniyordu. Dolayısıyla bir bakıma hastanelerin sundukları hizmetlerin kalitesi de ölçülmüş oluyordu. Buradan da anlaşılacağı üzere performans yönetimi ve toplam kalite yönetimi birbirini tamamlayan çağdaş yönetim yaklaşımlarıdır.

\subsection{Toplantı Yönetimi}

Dünya aralarında bilgi alış verişi yapmak, çeşitli planlar hazırlamak, mevcut sorunları halletmek, tenkitlerde bulunmak, dua ve ibadet etmek, yeni bazı kararlara varmak ya da önceden alınmış kararların eksik taraflarını bulup düzeltmek gibi amaçlarla bir araya gelen küçük gruplardan oluşmuştur. Örneğin iş yerleri, okullar, ailelerin vs. hepsi erkek kadın ve çocuklardan ibaret gruplardan meydana gelir. Değer hükümleri ve amaçları ne olursa olsun bu değişik grupların üyeleri, fonksiyonlarını yerine getirebilmek için bir araya gelmek zorundadırlar. Üç ya da daha fazla kişinin bir araya gelerek yüz yüze bir çalışma içine girmelerine toplantı denir (Doyle ve Straus, 1982: 11). Literatürde yer alan diğer toplantı tanımlarından bazıları; Birden fazla kişinin bir sorun, olay ya da olgu üzerinde görüşme yapmak amacıyla bir araya gelmeleri; özel bir iş konusunda görüşmek üzere iki veya daha fazla kişinin bir araya gelmesi; bir grup insanın belirlenmiş bir konuyu, bir başkanın yöneticiliğinde tartışmak üzere bir araya gelmesi şeklindedir (Şen, 2013: 4).

Periyodik toplantılar düzenlemek, yönetimde homojenliği sağlamanın en etkin yoludur. Yönetimde, hem sağlıklı bilgi alışverişi, hem de sorunların tartışılması ve rasyonel kararlar alınması ancak toplantı yönetimiyle mümkün olur. Ayrıca toplantılar, personeli yönetici etrafında birleştirir ve personeli de bütünleştirir. Böylece yönetimde ilke birliği sağlanmış olur; dedikodu yapılması, fısıltı gazetesinin yayılması ve söylentiler çıkması önlenir. O yüzden her hafta başı ast yöneticilerle ve her aybaşı personelle toplantılar gerçekleştirerek yüz yüze gelmekte fayda vardır (Aytürk, 1990: 169). Ancak şunu da belirtmek gerekir ki sadece belli durumlar da toplantı düzenlemek faydalı sonuçlar doğurur.

Gruptan bilgi ya da tavsiyeler bekleniyorsa, grubun karar verme ya da sorun çözmeye katılması isteniyorsa, bir meselenin açıklığa kavuşturulması gerekiyorsa, bir bütün olarak grupla paylaşılmak istenen bir mesele varsa, grup tarafindan toplantı yapılması istendiğinde, değişik gruplardan kişileri ilgilendiren bir konu olduğunda, ortada çok açık olmayan ya da 
kimleri ilgilendirdiği tam belli olmayan bir problem varsa eğer yönetici toplantı düzenlemelidir (Doyle ve Straus, 1982: 200). Ancak bu sayılanların ya da buna benzer durumların dişında toplantı yapılmamalıdır. Çünkü toplantı yapmaya gerek olmayan durumlarda toplantı yapmak zaman kaybıdır. Ve bu kayıp bazen bireysel bazen de örgütsel boyutta olabilir.

Toplantının ne zaman ve hangi durumlarda yapılacağı önemli bir husustur. Bunun için yönetici toplantı için uygun zamanı ve durumu belirlemeli, gerçekten toplantıya gereksinim olup olmadığını iyi düşünmeli ya da ihtiyaç hissettiği durumları iyi ve doğru seçmelidir (Aydın ve Taş, 2013: 72).

Her toplantı, yöneticiliğin ve liderliğin tezahür ettiği küçük bir yönetim merkezidir. Bu sebeple, toplantı yönetmek önemli ve aynı zamanda zor bir iştir; belli nitelik ve yetenek gerektirir. Her şeyden evvel, toplantı yönetimi konusunda bilgili, yetenekli ve deneyimli olmak gereklidir. Çünkü toplantı yönetiminin pek çok faydası olduğu gibi zararlı tarafları da bulunmaktadır. O yüzden, toplantıları başarılı ve faydalı kılmak, yöneticinin bilgi, beceri ve yeteneğine bağlıdır. Bu nedenle, her yönetici toplantı sanatını, toplantı yönetimini ve tekniklerini iyi bilmek zorundadır. Çünkü araştırmalara göre, yöneticiler zamanlarının çoğunu toplant1larda geçirmektedirler (Aytürk, 1990: 169).

Eğer toplantılar gösteriş ve boş laflardan ibaret değilse, grubun ya da teşkilatın sıhhatli çalışması noktasında büyük önem taşır. Grup üyelerinin grup bilincini geliştirmeleri ancak aynı yerde toplanarak birlikte çalışmaları ile mümkün olur. Bu toplantılar kişilerin kendi gruplarını nasıl gördükleri; kararlara ne şekilde katıldıkları; gerek ekip halinde, gerekse tek başlarına ne kadar iyi çalışabildikleri üzerinde doğrudan tesir yapar. Toplantıların çoğu da su yüzündeki halkalanmalar gibi bir etki meydana getirir. On beş kişinin yaptığı bir toplantı, günün geri kalan kısmında ya da bir hafta boyunca ya da sonsuza kadar 300 kişinin nasıl çalışacaklarına etki edebilir. Bu etki, bir kuruluş için olumlu ya da olumsuz olabilir. Kendisinden çok şeyler beklenen bir toplantı sonunda hiçbir şey başarılamaz ya da katılımcılar hayal kırıklığına uğrayıp asabileşirlerse, bu asabi halleriyle işlerine ya da evlerine döneceklerdir. Sonuçta katılımcılar sükunet bulmak için sadece kendi zamanlarını israf etmekle kalmaz, aynı zamanda çevredekilerin zamanları da berbat ederler. Bunlar başarısızlıkla sonuçlanan toplantıların gizli zararlarındadır (Doyle ve Straus, 1982: 18-19).

Toplantılar iyi yönetilmediğinde genellikle verimsiz ve karşılıklı tartışmalarla geçer. $\mathrm{Bu}$, hem yönetim için çok değerli olan zamanı alır hem de stres yaratır (Aydın, 2015: 246). Verimsiz toplantıların nedenleri arasında; toplantı amacına uygun olmayan ortam, uygun 
olmayan oturma düzeni, kişisel çatışma ve sürtüşmelerin toplantıya yansıması, toplantının amacından uzaklaşması, karşılıklı suçlama ve eleştiriler, yöneticinin grubu idare etmede güçlük çekmesi, grubun kendi aralarında konuşması, kontrolün devamlı eleştirenlerin eline geçmesi, karşılıklı güven bunalımının oluşması, katılımcıların görüş ve önerilerinin dikkate alınmaması yer almaktadır (Şen, 2013: 20-21).

Gerek kamu sektöründe gerekse özel sektörde sayısız toplantılar gerçekleştirilmektedir. Her bir toplantının konusu birimden birime farklılık gösterebilmekle birlikte bütün toplantıların temeli, kurumda çalışan ilgili personelle bir araya gelerek ilgili konu ya da konular hakkında bilgi alış verişinde bulunulması, geleceğe yönelik stratejik kararların alınmak istenmesi, meydana gelen durum ya da olayların görüşülmesi gerekliliği, yapılan ya da yapılacak olan değişikliklerin personele bildirilmesi vs. daha pek çok nedenden dolayı çeşitli toplantılar düzenlenmektedir. Adı üzerinde insanların toplanması bir araya gelmesinin söz konusu olduğu toplantılarda, belli bir konu üzerinde konuşup tartışarak sonuca ulaşılmak istenirken bir bakıma orada bulunan bütün bireylerin konu üzerinde düşünmeleri, fikirlerini söylemeleri istenmektedir ya da en azından istenmelidir. Yani toplantıdaki amaç, toplantıya çağırılan insanların sadece bir kişinin ya da bir grubun aldığ 1 kararların kabul etmesi istenmemeli, eğer toplu fikir alış verişinin gerçekleştirilmesi gerekiyorsa bu yapılmalı, aksi taktirde sadece toplantı yapmış olmak için toplantı düzenlenmemelidir. Sonuç olarak toplantıya çağırılan bireylerin fikirleri alınmalı, toplantıda bulunan herkesin katılımı sağlanmalıdır. Çünkü bir kişi toplantıya çağrıldıysa en azından çalıştığı birimi ya da kişiyi ilgilendiren bir durum var demektir. Ayrıca demokratik bir yönetim anlayışına giden yolda bu toplantıların nasıl düzenlendiği ve nasıl yönetildiği yolundan geçer.

Toplantı yönetimi sağlık yönetiminin tamamını kapsayan bir çağdaş yönetim yaklaşımıdır. Örneğin; planlama yapılırken, önemli kararlar alınırken, kalitenin ya da performansın değerlendirilmesi sirasında ya da sonrasında vb. durumlarda toplantılar düzenlenir ve çalışanlar bir araya gelir. Toplantıların başarılı bir şekilde gerçekleşmesi ve dolayısıyla toplantıyı yöneten kişinin toplantı yönetimi başarılı bir şekilde gerçekleştirmiş olması kurumun başarısını olumlu yönde etkiler. Çalışanların işlerine motive olmuş bir şekilde dönmelerini sağlar ve dolayısıyla bu durum kurumun hem kalitesini hem de performansını etkiler. Buradan toplantı yönetiminin gerek performans gerekse toplam kalite yönetimi anlayışı ile yakından ilgili olduğunu göstermektedir.

\section{SONUÇ}


Çă̆daş yönetim yaklaşımları yönetimde insan unsurunu önemseyen, ön plana çıkaran yaklaşımlar olarak nitelendirilebilir. Bu nedenle çağdaş yönetim yaklaşımları, kamu ya da özel sektör ayrımı olmadan her kurumda uygulanabilecek yaklaşımlardır. Her bir yaklaşımın diğeri ile yakından ilişkisi olup, diğer yaklaşımı tamamladığı görülür. Bu yaklaşımların herhangi bir kurumda uygulanması halinde yönetimde verimlilik ve etkinlik artar, insan ilişkileri daha iyi bir düzeyde seyreder, gerek kurumda çalışan personelin kalitesinde gerekse üretilen hizmet ve/veya ürünlerin kalitesinde artış görülür. Dolayısıyla yönetimde çağdaş bir yönetim tarzı oluşturulmuş olur.

Çağdaş yönetim yaklaşımlarının sağlık yönetiminde uygulanması diğer kurumlardan farklı olarak daha çok önem arz eder. Çünkü sağlık yönetimi öncelikli olarak insan hayatının devamını sağlayabilmek için sağlık ürün ve hizmetleri üretir. Bu nedenle, çağdaş yönetim yaklaşımları olarak nitelendirilen yaklaşımların hepsi örneğin; toplam kalite yönetimi, değişim yönetimi, stratejik yönetim, zaman yönetimi, stres yönetimi, performans yönetimi, kriz yönetimi, risk yönetimi çatışma yönetimi, kariyer yönetimi, süreç yönetimi, toplantı yönetimi, bilgi yönetimi, kalabalık yönetimi vb. sağlık yönetiminde uygulanabilir/uygulanması gerekir. Çağdaş bir yönetim tarzını yakalamak isteyen her yöneticinin çağdaş yönetim yaklaşımlarını bilmesi ve uygulaması gerekir.

Bu nedenle yukarı da çağdaş yönetim yaklaşımlarını temsil etmesi bakımından toplam kalite yönetimi, performans yönetimi ve toplantı yönetimi açıklanmıştır. Örneğin, bu yaklaşımlardan ilki olan toplam kalite yönetiminin temelinde hata yapmamak ve insan odaklı olmak anlayışının yer alması sağlık yönetimi açısından önemlidir. Çünkü toplam kalite anlayışının sağlık yönetimine adapte edilmesi kaliteli sağlık hizmetinin üretilip sunulması anlamına gelir. Toplam kalite yönetimi anlayışından yoksun bir sağlık sektöründe, doğrudan insan sağlığının etkileneceği akla getirilmelidir. Sadece bu sebepten dolayı bile en başta sağlık sektörü olmak üzere tüm kamu/işletme kurum ve kuruluşları bu anlayışa sahip bir yönetim anlayışı benimsemelidir.

Ayrıca sağlık ile ilişkili olduğu düşünülen diğer bir çağdaş yönetim anlayışı olarak toplantı yönetimi açıklandı. Sağlık ile ilgili konuşmak üzere çeşitli kurum ve kuruluşlarda (en başta Sağlık Bakanlığg olmak üzere, hastaneler ve diğer ilgili kurum ve kuruluşlarda) toplantılar düzenlenmektedir. Bu toplantılarda toplumun/bireyin sağlı̆̆ ile ilgili şimdiki ve gelecekteki durumu ile ilgili konular görüşülmektedir. Sağlık sektöründe toplantı yönetimine gereken özen gösterilmelidir. Çünkü bireyin dolayısıyla tüm vatandaşların sağlığını yani yaşamlarını kaliteli 
bir şekilde devam ettirip ettiremeyecekleri bir bakıma bu toplantıların verimli geçip geçmediğine bağlıdır.

Toplam kalite yönetimi, performans yönetimi ve toplantı yönetimi yaklaşımlarının her biri tecrübeli ve iyi eğitimli yöneticiler tarafından bilinçli bir şekilde titizlikle uygulandığ taktirde etkili ve verimli bir yönetim anlayışı gelişmiş olacaktır. Çünkü yaklaşımların hepsinde ortak olan amaç yönetimi etkili ve verimli kılmaktır. Yönetimin etkili ve verimli kılınması sonucu ise kamu örgütlenmesinin ilk ve en önemli amacı olan kamu yararı dolayısıyla halka hizmet en iyi şekilde gerçekleşmiş olacaktır. Aynı sonuç işletme yönetimi ya da diğer bir ifadeyle özel sektör içinde geçerlidir. Zaten tüm yönetim teorilerinin ve yönetim yaklaşımlarının ortaya çıkmasında ve bunlara her geçen gün yeni teorilerin ve yaklaşımların eklenmesindeki amaç yönetim sürecinin daha da iyileştirilmesi ve kusursuz bir yönetim gerçekleştirilmesini mümkün kılmaktır. Doğal olarak ortaya çıkan sonuçtan ilk olarak etkilenecek olan ise yine halktır ve/veya müşteridir. Bu nedenle her bir yönetim yaklaşımı kendi içerisinde iyi değerlendirilmeli, değişen ve gelişen şartlara gerek kamu kurumları gerekse işletme sahipleri ve onu yöneten yöneticiler başta olmak üzere personel iyi bir şekilde adapte olmalidir.

\section{REFERENCES / KAYNAKLAR}

Akçakaya, M. (2010). 21.yüzyılda yeni liderlik anlayışı. Ankara: Adalet Yayınevi.

Akgül, A. (1999). Toplam kalite yönetim sistemi. Yeni Türkiye Dergisi, 26(5), 35-58.

Akgül, A. \& Vural, O. (1999). Sanayi ve Ticaret Bakanlı̆̆ı'nda toplam kalite yönetim uygulamasl. Ankara: Kamu Yönetiminde Kalite I.Ulusal Kongresi II. Cilt. Türkiye ve Ortadoğu Amme İdaresi Enstitüsü Yayın no:289.

Aktan, C. C. (1999). Çăğdaş yönetim anlayışı: Toplam kalite. Yeni Türkiye Dergisi, 26(5), 68-84.

Aktan, C. C. (2005). Toplam kalite yönetiminin temelleri ve kamu yönetiminde uygulanması. İçinde C. C. Aktan \& U. Saran (Ed.), Kamu yönetiminde ve kamu hizmetlerinde kalite (ss. 65-87). Ankara: Hizmet-İş Sendikası Yayınları.

Aydın, A. H. (1999). Yönetimde çağdaş yaklaşımlar. Türk İdare Dergisi, 422(71), 13-20.

Aydın, A. H. (2004). Türk kamu yönetimi sisteminde temel sorunlar ve çağdaş yaklaşımlar. Ankara: Gazi Kitabevi.

Aydın, A. H. (2006). Kamu yönetimi ve polis. Ankara: Gazi Kitabevi.

Aydın, A. H. (2011). Yönetim bilimi. Ankara: Seçkin Yayıncılık.

Aydın, A. H. (2012). Kamu yönetimine giriş. Ankara: Seçkin Yayıncılık. 


\section{Gök, S.}

Aydın, A. H. (2015). Yönetim bilimi. Ankara: Seçkin Yayıncılık.

Aydın, A. H. \& Taş, İ. E. (2013). Kamu yönetiminde halkla ilişskiler kavramlar-kurumlar uygulamalar. Ankara: Seçkin Yayıncılık.

Aytürk, N. (1990). Başarll yönetim ve yöneticilik teknikleri yönetim sanatı. Ankara: Emel Yayınevi.

Çelik, Y. (2012). Örgüt teorileri ve sağlık kurumları yönetimi. İçinde M. Tatar (Ed.), Sağlk kurumları yönetimi I (ss.76-136). Eskişehir: Anadolu Üniversitesi Yayınları.

Çevik, H. H. (2001). Türkiye’de kamu yönetimi sorunları. Ankara: Seçkin Yayıncılık.

Doyle, M. \& Straus, D. (1982). Toplantı yapma sanatı (R. Saruhan, Çev.). İstanbul: Yeni Asya Yayınları.

Drucker, P. F. \& Maciariello, J. A. (2005). Gün gün Drucker - ünlü düşünürün yapıtlarından seçilmişs 366 fikir ve motivasyon. İstanbul: The Daily Drucker Harper Business, Mess Yayın No: 469.

Ergun, T. (2015). Kamu yönetimi kuram-siyasa-uygulama. Ankara: TODAİE.

Ergun, T. \& Polatoğlu, A. (1988). Kamu yönetimine giriş. Ankara: TODAİE Yayınları No: 222.

Eryılmaz, B. (2009). Kamu yönetimi düşünceler-/yapılar/fonksiyonlar/politikalar. Ankara: Okutman Yayıncılık.

Fişek, K. (1975). Yönetim. Ankara: SBF Yayını No:387 AÜ.

Fişek, N. H. (1983). Halk sağllğına giriş. Ankara: Hacettepe Üniversitesi-Dünya Sağllk Örgütü Hizmet Araştırma ve Araştırıcı Yetiştirme Merkezi Yayını No: 2.

Işık, M., Öztekin, A., Öztekin, H. \& Biber, L. (2013). Genel ve teknik iletişim. Konya: Eğitim Yayın Evi.

Kavuncubaşı, Ş. (2002). Sağlık kurumları işletmeciliği. İçinde N. Uzkesici (Ed.), Sağllk kurumları yönetimi (ss. 47-66). Eskişehir: Anadolu Üniversitesi Yayınları.

Kavuncubaşı, Ş. \& Yıldırım, S. (2012). Hastane ve sağllk kurumları yönetimi. Ankara: Siyasal Yayınevi.

Koç, H. \& Topaloğlu, M. (2012). Yönetim bilimi-temel kavramlar, kuramlar ve ilkeler. Ankara: Seçkin Yayıncılık.

March, J. G. \& Simon, H. A. (1975). Örgütler (Ö. Bozkurt \& O. Onaran, Çev.). Ankara: TODAİE Yayınları No: 144.

Paksoy, M. (2007). Toplam kalite yönetimi. İçinde S. Güney (Ed.), Yönetim ve organizasyon. Ankara: Nobel Yayın Dağıtım.

Parlak, B. (2013). Yönetim bilimi ve çağdaş yönetim teknikleri. İstanbul: Beta Basım Yayım Dağıtım.

Saruhan, Ş. C. \& Yıldız, M. L. (2013). Çağdaş yönetim bilimi. İstanbul: Beta Basım Yayım Dağıtım.

Simon, H. A. \& Smithburg, D. W. \& Thompson, V. A. (1985). Kamu yönetimi (C. Mihçıŏlu, Çev.). Ankara: SBF Yayınları.

Sözen, C. (2003). Sağllk yönetimi. Ankara: Palme Yayıncılık.

Şahin, Y. (2015). Yönetim bilimi ve Türk kamu yönetimi. Bursa: Ekin Basım Yayın Dă̆ııım.

Şen, O. (2013). Toplantılara kavramsal yaklaşım. İçinde A. A. Doğan (Ed.), Toplantı ve sunu teknikleri. Eskişehir: Anadolu Üniversitesi.

Tengilimoğlu, D., Işık, O. \& Akbolat, M. (2014). Sağlık işletmeleri yönetimi. Ankara: Nobel Yayınları. 
Tortop, N. \& İsbir, E. G. \& Aykaç, B. (2010). Yönetim bilimi. Ankara: Yargı Yayınevi.

Yatkın, A. (2004). Toplam kalite yönetimi. Ankara: Nobel Yayın Dağıtım. 